\title{
APPLICATION OF EVERYONE IS A TEACHER HERE LEARNING MODEL TO IMPROVE SELF CONFIDENCE STUDENTS
}

\author{
Anugrah Ramadhan Firdaus \\ IKIP Siliwangi \\ arf432@gmail.com
}

\begin{abstract}
This research is motivated by some students problems about the belief in its ability. This is based on early observation of one-way learning so that students are not used to speaking in front of many people. One of the efforts is to improve self-confidence by applying the learning model of everyone is a teacher here. The objectives to be achieved in this research are: (1) to express the implementation of learning by applying the learning model of everyone is a teacher here to improve student self confidence, (2) To express the improvement of self confidence of students after applying the learning model of everyone is a teacher here. This study is a classroom action research adapted from the Kemmis and Mc model. Taggart. This research was conducted in Grade 4 which amounted to 30 students. The results obtained from the learning process has progressed from cycle I to cycle II. Negative findings found in cycle I amounted to 10, while negative findings in cycle II amounted to two. From the data it is recommended to teachers to use the learning model of everyone is a teacher here to improve student self confidence.
\end{abstract}

Keywords: Model everyone is a teacher here, self confidence student.

\begin{abstract}
Abstrak
Penelitian ini dilatarbelakangi oleh beberapa permasalahan siswa tentang keyakinan pada kemampuannya. Hal ini berdasarkan pada observasi awal yang terjadi pembelajaran satu arah sehingga siswa tidak terbiasa untuk berbicara di depan banyak orang. Salah satu upaya yang dilakukan yaitu dengan meningkatkan self confidence siswa dengan menerapkan model pembelajaran everyone is a teacher here. Tujuan yang hendak dicapai dalam penelitian ini adalah: (1) mengungkapkan pelaksanaan pembelajaran dengan menerapkan model pembelajaran everyone is a teacher here untuk meningkatkan self confidence siswa, (2) Mengungkapkan peningkatan self confidence siswa setelah menerapkan model pembelajaran everyone is a teacher here. Penelitian ini merupakan penelitian tindakan kelas yang diadaptasi dari model Kemmis dan Mc. Taggart. Penelitian ini dilakukan pada kelas 4 yang berjumlah 30 siswa. Hasil penelitian diperoleh proses pembelajaran mengalami perkembangan dari siklus I ke siklus II. Temuan negatif yang ditemukan pada siklus I berjumlah 10, sedangkan temuan negatif pada siklus II berjumlah dua. Dari data maka direkomendasikan kepada para guru untuk menggunakan model pembelajaran everyone is a teacher here untuk meningkatkan self confidence siswa.
\end{abstract}

Kata kunci: Model everyone is a teacher here, self confidence siswa.

\section{INTRODUCTION}

Background of the observations made at high class in one of the primary schools in Bandung, researchers found the problem that many learners who have self confidence is still low. Seen from the observation of the researcher during the learning took a look at several problems such as: (1) The learning took place in one direction, the teacher explained the material with the lecture method, (2) Students seen often chatting with his friends but passive when discussion about learning, (3) ) When the learner is asked to give an opinion by the 
teacher no one wants to express their opinions voluntarily, just looks grumpy in the mouth only, (4) Dare to answer questions simultaneously, (5) When learning is done in groups it is difficult to determine the group leader, (6) After discussion group difficult to communicate result of group discussion.

After identified the students of the class turned out to have a low self-confidence because students have a fear of ridicule from other friends if the answer that the student pointed out wrong, other than that students feel afraid when making mistakes will be scolded by the teacher because of high grade teacher tone to impress the students are reluctant to answer the questions in front of the class or give an opinion when the learning activities take place.

Referring to previous research by Ariny (2014) entitled "Application of Cooperative Learning Learning Through Everyone Is Teacher Here Method in Increasing Student Confidence in IPS Learning." The result of this research is: The result of IPS learning by applying the method Everyone is teacher here in each cycle has increased. In cycle 1 the acquisition of learners who are said to have confidence is only $57.5 \%$. The gain in cycle 2 is only $69.69 \%$. While the acquisition in cycle 3 that is as much as $87.87 \%$. When viewed from the above explanation can be seen increased confidence increased in each cycle from cycle 1 to cycle 3 .

Therefore in this case the authors propose the use of the model of everyone is teacher here to train students boldly speaking in front of the class, issuing opinions, dare to ask or refute the opinion of friends who are felt not appropriate. With self-confidence embedded in students, the learning process will become more lively, creating an active, effective and enjoyable classroom atmosphere for students and teachers. Based on what is stated above, the authors choose the title of research "Application of Learning Model Everyone Is A Teacher Here To Improve Student Self Confidence."

\section{METHODE}

The method used in this research is qualitative with Classroom Action Research (PTK) or Classroom Action Research (CAR) technique. In this research to improve self confidence of students, the researcher will apply the learning model of everyone is a teacher here by referring to the self confidence assessment according to Lauster (Megawati, 2010, pp. 21) as follows. 
a. Students play a role as a teacher and explain the teaching materials that will be delivered in front of the class can increase confidence in the ability of self-owned.

b. Students come to the front of the class and answer questions posed with logical reasons can improve the positive self-concept.

c. Students able to give an opinion on answers from friends can increase students' courage when giving an opinion.

d. Students are able to refute the opinion of friends who are considered less appropriate to improve independent attitude in making decisions

The model used in this study is modified from the method of everyone is a teacher here according to Mil Siberman, Then the steps of applying the model of everyone is teacher here as follows.

a. Students and teachers do question and answer to explore the students' initial knowledge about the material to be discussed in the learning process.

b. Students listen to the teacher's experience as an example of a problem they have faced.

c. Students are divided into groups.

d. Each group is given different teaching materials with other groups.

e. Students observe images of teaching materials that teachers provide.

f. Students conduct group discussions on teaching materials that have been determined by the teacher.

g. Volunteers from each group explained the material that had been determined in front of the class.

h. Students are given index cards to make inquiries of the material being studied.

i. The card is collected and the teacher scrambles the card and reshares it to the students.

j. Students are asked to read the questions in the heart of the card and prepare questions.

$\mathrm{k}$. Volunteers read the questions aloud in front of the class and then spontaneously answered the question.

1. Other students give opinions or disprove what volunteers have answered.

m. Continue as long as there are volunteers

Table 1 Linkages Self-Confidence Indicator with step learning model everyone is a teacher here 


\begin{tabular}{cc}
\hline Have confidence in your own ability & here \\
Optimistic & $\begin{array}{c}\text { Become a volunteer as a teacher and } \\
\text { explain the material in front of the class } \\
\text { Answer the questions on the index card } \\
\text { in front of the class }\end{array}$ \\
Rational and Realistic & Express opinions for logical reasons \\
\hline
\end{tabular}

\section{RESULTS AND DISCUSSION}

Increased self-confidence of students obtained from the observations made by the observer. In the self confidence assessment sheets there are three indicators that reflect the students have high self confidence, that is belief in self-ability, optimistic and rational and realistic. In the application of indicators of confidence in the ability of oneself can be seen when students are able to play the role of teachers and explain the material in front of the class. Optimistic indicators in its application can be seen when students are brave to answer questions in front of the class, and a third indicator that is rational and realistic can be seen when students dare to express their opinions along with logical reasons.

Observations made by the observer to see the self confidence of students was still a lot of students who have low self confidence. Seen from activities that occur during learning. Learning is divided into five groups then there are five volunteer group representatives. The division of random groups is not determined by the teacher but by counting. Group one consisted of TSA, RAN and YNR which included students with low thinking ability, CAK and DRS which included students having medium-thinking ability and SAA with high thinking ability. In the second group consisting of DPA and CAS which included students having low-thinking skills, MLA and MN which included students having moderate skills, DMF and ROS that included high-thinking students. In groups of three, there were AKRs that included students with moderate thinking skills, AR and VSN who had low thinking skills, IDP, AAD and MAF who included students with high thinking skills. Group four consisted of NKM and HD which included students of moderate thinking skills, BEH, RAL and AF which included having low thinking ability and WNA that included in high thinking ability. In the five groups consisting of CZN, KD and DA which included students having mediumthinking skills as well as RFN, AAB and NAN which included students having high thinking ability.

Table 2 Students Serving As Teachers In Implementation Cycle I

\begin{tabular}{ccccc}
\hline \multicolumn{5}{c}{ Dare to play a role as a teacher } \\
\hline Group 1 & Group 2 & Group 3 & Group 4 & Group 5 \\
\hline
\end{tabular}




\begin{tabular}{lllll}
\hline SAA & AAD & ROS & WNA & RFN \\
\hline
\end{tabular}

Based on the observer observations from five volunteers who became teachers only three people who really want to be representative of the group to become the other two teachers for the compulsion of his group friends.

Table 3 Students who Answer Questions and Express Opinions

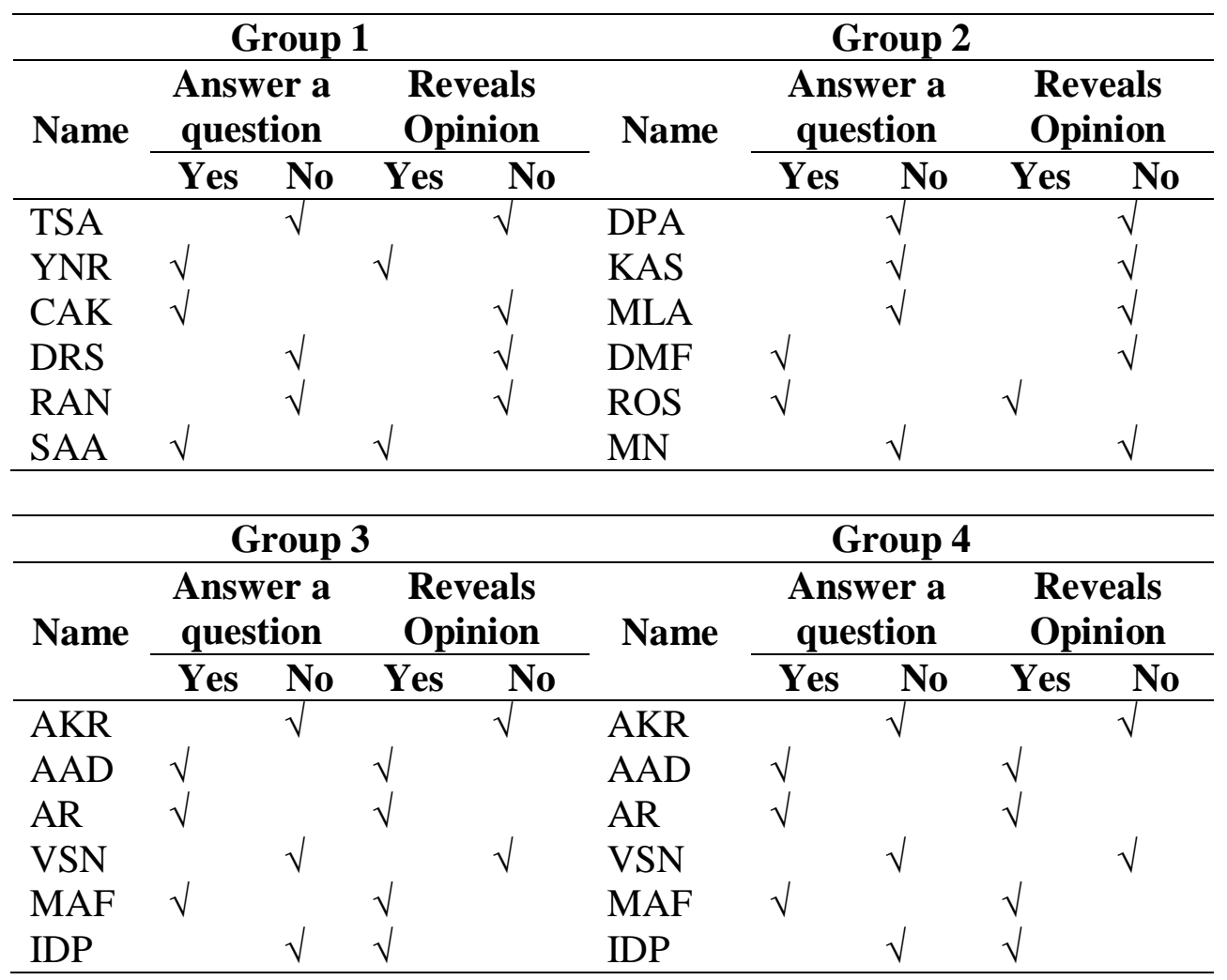

\begin{tabular}{|c|c|c|c|c|}
\hline \multicolumn{5}{|c|}{ Group 5} \\
\hline \multirow[t]{2}{*}{ Name } & \multicolumn{2}{|c|}{$\begin{array}{c}\text { Answer a } \\
\text { question }\end{array}$} & \multicolumn{2}{|c|}{$\begin{array}{l}\text { Reveals } \\
\text { Opinion }\end{array}$} \\
\hline & Yes & No & Yes & No \\
\hline $\mathrm{CZS}$ & $\sqrt{ }$ & & $\sqrt{ }$ & \\
\hline KD & & $\sqrt{ }$ & & $\sqrt{ }$ \\
\hline RFN & $\sqrt{ }$ & & & $\sqrt{ }$ \\
\hline $\mathrm{AAB}$ & & $\sqrt{ }$ & & $\sqrt{ }$ \\
\hline DA & & $\sqrt{ }$ & & $\sqrt{ }$ \\
\hline NAN & & $\sqrt{ }$ & & $\sqrt{ }$ \\
\hline
\end{tabular}


The next two aspects of assessment are the optimists reflected in students who dare to answer questions in front of the class. Other indicators are rational and realistic reflected in students who dare to express opinions during class discussions. Based on the observer observation it is seen that not always students who have high thinking ability also have high self confidence.

\section{RESULT AND DISCUSSION}

Based on the observations made by the three observers it can be concluded learning activities undertaken by researchers as follows. In the introduction the lesson begins with the conditioning of the students and proceeds to pray together led by the class leader. Furthermore, teachers check the presence of students by calling one by one the names of students and students who called in his name raised his hands and the teacher filled the book absent. After that the teacher prepares students to be ready to learn by giving motivation and concentration test game which is continued by doing apersepsi by doing question and answer about social problem.

After the teacher apperception tells the story of his experience when getting the problem, then the students categorize the problem including on personal issues or social problems. Entry into the core activities of students is divided into five groups. Each group was given teaching materials on social problems that occurred in different neighborhoods, one on poverty, group two on crime, group three on juvenile delinquency, group four on unemployment and group five on waste issues .

Students conduct group discussions on materials that have been determined by the teacher as well as preparation for the volunteers who will play the role of teachers and explain the material in front of the class. The implementation of the learning model of everyone is a teacher here when volunteers from each group act as teachers. Serve as a teacher and explain the material in front of the class is the implementation of one indicator of self confidence is self-belief and when all students make a question on the index paper and volunteers who dare to answer questions his friends in front of the class. Answering the question is the implementation of the second indicator of self confidence is optimistic.

Completed discussion of volunteers from each group explained the material in front of the class in turn. Another student listens to the explanation from his teacher. There are five 
volunteers who play the role of the teacher then reflected there are five students who have shown confidence in their own ability. After each volunteer explains in front of the class then the teacher distributes the index cards that students use to write questions. Questions are directed to the material already described by volunteers who act as teachers who are still not understood by the students. After the student writes the question the index card is collected on the classroom teacher then the teacher class scrambles the index card and reshares it to all students. Furthermore, students are asked to read in the heart of the questions that he got.

The teacher invites the courageous students to answer the questions she gets in front of the class. These activities reflect the students have an optimistic attitude that is the second indicator of self confidence. The third self-confidence indicator is reflected when the student expresses an opinion or refutes the opinion of the answers to the student questions raised in front of the class. Expressing opinions reflects rational and realistic indicators. These three indicators refer to how self-esteem self-assessed by Lauster (Megawati, 2010, pp. 21).

Students then sit back to their seats as if they were not in groups. Students with teachers conclude the material that has been studied by doing question and answer, then the students work on the evaluation of individuals and teachers around to supervise in order to avoid cheating.

The final step in the learning activities is closing activities. The teacher closes the learning by giving motivation to the students to be more active to learn and can be more confident in their ability to not always feel ashamed to appear in front of the class, then the teacher closes the learning.

Based on the conclusions of the observations, the teacher has applied the learning model of everyone is a teacher here but there are still activities that are not done that is giving the students opportunity to share their experiences when facing personal problems and social problems. The Observer notes the important note that it is advisable that when the lesson takes place the teacher continues to motivate and give the students more courage to express their opinions.

\section{CONCLUSION}

Based on the results of research that has been done, there are several conclusions obtained as follows: 
1. The learning process progressed from cycle I to cycle II. In the second cycle, the learning process, especially in the grouping stage and explanation of volunteers, has changed, namely group changes in accordance with the students' wishes and reexplanation by the teacher after the explanation of the volunteers. This is done so that students do not feel awkward in doing group discussion and students are more understanding about the learning materials delivered by volunteers.

2. Self confidence of students has increased from cycle I to cycle II. In the second cycle of self-confidence, optimism and rationality of students began to increase. This is due to the change of learning process from cycle I to cycle II, namely in step grouping students and explanation of learning materials by volunteers. With the change of grouping according to the students want, the students no longer feel awkward and increase their confidence. With the re-explanation by the teacher after the explanation of the volunteers, students increasingly understand the learning materials. This results in increased self-confidence, rationality and student optimism.

\section{REFERENCES}

Arikunto, S. Dkk. (2011) Penelitian Tindakan Kelas. Jakarta: PT Bumi Aksara.

Ariny. (2014). Penerapan Pembelajaran Cooperative Learning Melalui Metode Everyone Is Teacher Here dalam Meningkatkan Rasa Percaya Diri Siswa dalam Pembelajaran IPS. Skripsi UPI. Tidak diterbitkan.

Farhan, Abu. (2012). Self Confidence.[Online].Tersedia: http://abufarhanalir.blogspot.com/2012/05/kepercayaan-diri-selfconfidence.html (17 Maret 2015)

Ghufron, M.Nuh. (2010). Teori-Teori Psikologi. Yogyakarta: AR-RUZZ Media Group.

Kusumah, Wijaya. (2010). Mengenal Penelitian Tindakan Kelas. Jakarta: Indeks.

Lumpkin, Aaron. (2004). Positive, Confident, and Courageous. Jakarta: Erlangga.

Megawati. (2010). Perbedaan self confidence siswa SMP yang aktif dan tidak aktif dalam organisasi siswa intra sekolah.[Online].Tersedia: http://repository.usu.ac.id/bitstream/handle/123456789/18153/Chapter\%20II.pdf ;jsessionid=7C5E1C433AA50C0DF17016FDC7118066? sequence=3 (17 Maret 2015)

Natalia, Margaretha Mega. (2008). Penelitian Tindakan Kelas. Bandung: Tinta Emas.

Prawira, Angga Khuzaifah.(2015).Profil Rasa Percaya diri siswa dan Implikasinya Terhadap Bimbingan dan Konseling. Skripsi UPI.Tidak diterbitkan. 
Journal of Elementary Education

Volume 2, Number 2, September 2018
P-ISSN: 2580-9326

E-ISSN: 2580-7714

Sanjaya, W. (2010) Penelitian Tindakan Kelas. Jakarta: Kencana Predana Media Group

Silberman, Mel. (2009). Active Learning.Yogyakarta: Pustaka Insan Madani.

Sugara, Robi Panji. (2014). Penerapan Model Pembelajaran Talking Stick Untuk Meningkatkan Kemampuan Berkomunikasi Siswa Pada Pembelajaran Ips Materi Persiapan Kemerdekaan Indonesia. Skripsi UPI. Tidak diterbitkan.

Sugiyono. (2013). Metode Penelitian Pendidikan. Bandung: Alfabeta

Suprijono, Agus. (2014). Cooperative Learning Teori dan Aplikasi. PAIKEM. Yogyakarta: Pustaka Pelajar. 